\title{
Differences in food assimilation between two coot species assessed with stable isotopes and particle size in faeces: Linking physiology and conservation
}

\author{
Nico Varo $\square$, Juan A. Amat \\ Department of Wetland Ecology, Estación Biológica de Doñana, C. S. I. C., Apartado 1056, E-41080 Sevilla, Spain
}

\begin{abstract}
The red-knobbed coot Fulica cristata experienced a dramatic population decline in Spain, where the common coot F. atra does not face conservation problems. This is puzzling because both species have similar ecologies. It has been suggested that habitat alterations affected the quality of food plants, and this impacted differentially both coots. To verify this, we conducted experiments to determine the assimilation efficiency of both species in relation to food quality. Two types of diets differing in fibre content (commercial food and Potamogeton pectinatus) were offered to captive red-knobbed and common coots, during both spring and autumn. We examined variations in faecal particle size among coot species and diets, indicative of the facility with which food can be assimilated, and used the stable isotope technique to study differences between coot species in stable isotope fractionations from consumption to excretion. Faecal particle size was larger in red-knobbed than in common coots when fibre content was high, but was similar when it was low. Faecal particle sizes were larger in autumn, when fibre content was higher, than in spring. In general, $\delta^{15} \mathrm{~N}$ in faeces of red-knobbed coots was greater than in faeces of common coots. These results suggest that the digestive efficiency of the red-knobbed coot was lower than that of the common coot, and that the differences increased when the fibre content in food plants increased. Managers should try to make available to coots wetland habitat with high quality food, which may be facilitated by prolonging the hydroperiods.
\end{abstract}

Keywords: Faecal particle size; Food assimilation efficiency; Herbivorous birds; Mediterranean wetlands; Physiological constraints; Stable isotopes; Waterbirds

\section{Introduction}

Herbivorous diets may pose serious assimilation problems to consumers. Although plants have easily metabolizable components, such as proteins and non-structural carbohydrates (Karasov, 1990), they also have structural components that make difficult their digestion (Drobney, 1984; Buchsbaum et al., 1986; López-Calleja and Bozinovic, 1999; Cornelissen et al., 2004). One such component is fibre, which for herbivorous birds may represent a constraint on food assimilation efficiency (Durant, 2003). Fibre is mainly composed of cellulose, hemicellulose and lignin, and although birds may digest some

\footnotetext{
Corresponding author. Tel.: +34 954232 340; fax: +34 954621125 . E-mail address: nico@ebd.csic.es (N. Varo).
}

cellulose and hemicellulose, they are not able to digest lignin (Durant, 2003). Because birds lack enzymes to digest fibre, they rely on symbiotic microbes. However, to facilitate digestion processes, birds have to break down their food items into smaller particles in the gizzard. This is because the smaller the particle sizes of the digesta, the easier its fermentation (Bjorndal et al., 1990), so that we should expect that bird species with a lower capacity in grinding their food into small particles should show lower assimilation efficiency.

It is important to know the efficiency with which food is assimilated because this determines the quantity of energy that animals obtain from their diets (Buchsbaum et al., 1986; Veloso and Bozinovic, 1993), as well as their fitness (Karasov, 1986). Therefore, a study on assimilation efficiencies may clarify in those cases in which closely related species relying on similar food types have different ecological performances. Such a case 
may be found in southern Spain with the red-knobbed Fulica cristata and common F. atra coots.

Red-knobbed and common coots are phylogenetically closely related (Livezey, 1998), ecologically similar rails, which are sympatric in a small portion of their ranges in the southwestern Palearctic (Cramp and Simmons, 1980). Given their similar ecologies, it is puzzling that in the sympatric range in Spain the red-knobbed coot, but not the common coot, faces serious conservation threats that led to the almost complete disappearance of the former species from this country in the 20th century, where it is critically endangered (Bernis, 1964; Amat and Raya, 2004). A recent comparative study on the breeding biology of both species in southern Spain showed a much lower breeding success for the red-knobbed than for the common coot, and also a negative relationship between the mean time that breeding adult red-knobbed coots spent foraging and the number of chicks raised per brood. This last relationship was not found for the common coot (Varo, 2007).

It has been suggested that, as a consequence of habitat alterations in wetlands, the quality of food available to redknobbed coots would be nowadays lower than when the species was more widely distributed in Spain (Amat and Raya, 2004). Under this scenario, the aim of our study was to examine whether the nutritional quality of food plants could affect differentially the assimilation efficiency of red-knobbed coots in relation to that of common coots. For this, we conducted a study comparing the assimilation efficiencies of both coot species in relation to the nutritional quality of foods. The occurrence of stable isotopes of $\mathrm{C}$ and $\mathrm{N}$ in tissues of consumers and their food has been widely used to reconstruct diets of animals and to study their feeding ecology (e. g., Hobson and Clark, 1992; Ganes et al., 1998; Carmichael et al., 2004; Fry, 2006). Some studies have used stable isotopes in faeces to get information on diets (e. g., Sponheimer et al., 2003a; Codron et al., 2005, 2007; Hwang et al., 2007), and some of them found that stable isotopes in faeces may not represent adequately the composition of diets, mainly because undigested components may be overrepresented (Sponheimer et al., 2003a,b; Codron et al., 2005). However, this over-representation of undigested components may be used to study the differences in food assimilation in closely related species fed with the same diets. Therefore, we compared stable isotopes composition in diets and faeces to assess food assimilation efficiencies in both coot species.

We predicted that the assimilation efficiency of the redknobbed coot would be lower than that of the common coot mainly when the quality of food plants diminishes (i. e., due to a higher fibre content), a situation that in southern Spain usually takes place in late summer-early autumn when declining water levels in wetlands affect negatively the production of submerged aquatic macrophytes, which is typical in Mediterranean-type wetlands (Van Wijk, 1988; Santamaría and Hootsmans, 1998; Menéndez, 2002). The higher fibre content of food would limit the size into which particles may be broken down during digestive processes (Van Soest, 1996). Thus, the differences in assimilation efficiencies between species would be related to a lower ability of red-knobbed coots to grind their food into small particles in comparison with common coots. It is important to document whether this is actually occurring because knowing the precise mechanisms that affect population performance may be essential for the successful implementation of conservation measures.

\section{Methods}

\subsection{Experimental protocol}

We conducted experiments with common and red-knobbed coots in captivity to determine the assimilation efficiency of each species, both in spring and autumn. In a pilot experiment we placed ten individuals of each species in individual cages $(1.0 \times 0.5 \times 0.5 \mathrm{~m})$. All individuals were visually isolated from the others. In spite of both water and food being provided ad libitum, most individuals lost body mass during the first week of isolation because they seemed to be stressed (see also Fairall, 1981). We therefore decided to use four outdoor aviaries $(2.5 \times 2.5 \times 2 \mathrm{~m})$. We used 16 adult individuals of each species (eight per aviary), though the identity of these individuals was different in spring and autumn. We recorded body masses, and did not find differences between the start and the end of the experiment, neither in spring (for red-knobbed coots: 706.4 \pm (SD) $65.7 \mathrm{~g}(\mathrm{n}=14)$ vs. $703.6 \pm 63.0 \mathrm{~g}$, respectively, Student's paired t-test, $\mathrm{t}=1.07, \mathrm{P}=0.302$; for common coots: $649.3 \pm 57.4$ $(n=15)$ g vs. $644.7 \pm 51.4$ g, respectively, paired $t=1.13$, $\mathrm{P}=0.278$ ), nor in autumn (for red-knobbed coots: $690.0 \pm$ $48.7 \mathrm{~g}(\mathrm{n}=12)$ vs. $682.3 \pm 51.3 \mathrm{~g}$, respectively, paired $\mathrm{t}=1.87$, $\mathrm{P}=0.09$; for common coots: $587.9 \pm 47.1 \mathrm{~g}(\mathrm{n}=13)$ vs. $580.7 \pm$ 49.2 g, respectively, paired $\mathrm{t}=1.86, \mathrm{P}=0.09$ ).

We used two diets: commercial bird food (Visán Industrias Zootécnicas, S. A., Madrid), and Potamogeton pectinatus. We used commercial food as a standard diet for seasonal comparisons, so that any seasonal difference in assimilation of natural foods could be attributed to variations in their quality, and not to seasonal variations in the physiology of coots. The submerged aquatic macrophyte was collected in wetlands of southwestern Spain, and is frequently consumed by both species (Cramp and Simmons, 1980; Fairall, 1981; Fernández-Palacios and Raya, 1991; Taylor and Van Perlo, 1998). The plants were collected in sites with monospecific stands. We collected all P. pectinatus samples in the Guadalquivir marshes. Nevertheless, due to a marked seasonality in the wetlands of SW Spain (Amat, 1984), it was not possible to collect the P. pectinatus samples in the same sites in spring and autumn, as the sites where the plants were collected in spring had dried out in autumn. The food plants were collected every season a day before we offered them to coots.

During six days prior to the start of the experiment, the coots were fed with commercial food to acclimate their digestive tracts (Ziswiler and Farner, 1972; Kehoe et al., 1988). After that, the birds were fed each type of diet during periods of two consecutive days, until the two diets were offered. Two days might not be long enough to know the real assimilation efficiency of the coots when they are being fed on a given food, but it may be long enough for comparative purposes (CaviedesVidal et al., 2000). The order with which each diet type was 
offered in spring and autumn was arbitrary, but was the same for both coot species. Total elimination of a meal occurred in less than $24 \mathrm{~h}$ (N. Varo and J. A. Amat, unpubl.). Therefore, the faeces produced during the first day after the coots were being fed on a given type of diet were discarded to avoid contamination with another diet type, and we only collected faeces during the second day after the coots were fed a same diet. We placed plastic trays on the floor of aviaries to facilitate the collection of faecal droppings. The aviaries were cleaned every morning. All droppings collected for analyses were dried during $48 \mathrm{~h}$ in an oven at $50{ }^{\circ} \mathrm{C}$, and then weighed and preserved in paper bags until analyses.

\subsection{Faecal particle size}

We examined individual droppings (93 in autumn and 91 in spring) to estimate faecal particle size according to coot species, diet type and season. Prior to examination, the droppings were soaked in water during $48 \mathrm{~h}$. The particles in each dropping were sorted into categories depending on their size by passing them through sieves with mesh diameter (mm) 0.125, 0.250, and 0.500 . Thus, four categories of particle size (mm) were obtained:b0.125 (category 1), 0.125-0.249 (category 2), $0.250-0.499$ (category 3 ), and $\geq 0.500$ (category 4 ). The droppings were washed throughout the sieves. Once sorted, the fractions of faecal particles within each category were dried at $50{ }^{\circ} \mathrm{C}$ during $24 \mathrm{~h}$, and then their masses recorded with an electronic balance to the nearest $0.1 \mathrm{mg}$. As particles b $0.125 \mathrm{~mm}$ were lost when the samples were washed, we estimated the mass of particles in this category for each dropping by subtracting the dry mass of the particles retained in the sieves from the total dry mass of the dropping.

To compare particle sizes among faeces, we calculated an index of faecal particle size (IPS ${ }_{\mathrm{i}}$ ) for each one of the four categories of faecal particle size, so that

IPS $_{\mathrm{i}} 1 / 4 \mathrm{~K}_{\mathrm{i}} \times \mathrm{P}_{\mathrm{i}}$

where $\mathrm{P}_{\mathrm{i}}$ was the proportion with which the $\mathrm{i}$ category was recorded in every sample, and $\mathrm{K}_{\mathrm{i}}$ is a constant for each one of the categories of particle size, being

$K_{i}^{1 / 4}$ ð $A_{i} p B_{i} p=2$

where $A_{i}$ and $B_{i}$ are, respectively, the lower and upper limits of particle size for the corresponding category. As the category 4 did not have an upper limit, we considered $\mathrm{K}_{4}=0.501$ to calculate its IPS, hence IPS for this category was conservative. We calculated IPS for every faecal dropping as the sum of IPS $\mathrm{S}_{\mathrm{i}}$ of the four categories of particle size in the corresponding sample. A lower IPS indicated a smaller the particle sizes in a faecal sample.

\subsection{Nutritional quality of foods and stable isotope analyses}

Samples of commercial food and submerged macrophytes were analyzed to characterize their content of fibre (cellulose + lignin) and protein, both in spring and autumn. Only a sample of each type of food was analyzed per season. Analyses were conducted in a commercial laboratory (Centro de Análisis Agropecuarios, S. A., Seville, Spain).

We used the stable isotopes technique to estimate differences in the assimilation efficiency (see Carmichael et al., 2004). Our analyses on food assimilation efficiency with this technique were limited to ${ }^{13} \mathrm{C} /{ }^{12} \mathrm{C}\left(\delta^{13} \mathrm{C}\right)$ and ${ }^{15} \mathrm{~N} /{ }^{14} \mathrm{~N}\left(\delta^{15} \mathrm{~N}\right)$ for the samples of commercial and natural foods and their faeces. The isotope concentrations of food fractionate when they are incorporated into the tissues of the consumers, and species using the same food may differ in the degree of isotope fractionation (Hobson and Clark, 1992; Sponheimer et al., 2003b). Therefore, these differences in the degree of isotope fractionation should be expressed in the concentrations of isotopes in the fraction that is not incorporated into the body tissues of the consumer. That is, differences of isotope ratios in faeces relative to those in diets between the red-knobbed and common coot would suggest differential assimilation efficiency of foods in both species.

We collected P. pectinatus, and stored it in sealed plastic bags until transport to the laboratory, where it was washed thoroughly to remove periphyton. Although the removal of periphyton is less effective from plants with narrow leaves, such as $\mathrm{P}$. pectinatus, the biomass of remaining attached periphyton is unlikely to influence significantly the stable isotope values of macrophytes (Jones et al., 2004). Five samples of foods (aquatic plants and commercial food) and five individual faeces of each coot species for each type of diet were oven dried at $50{ }^{\circ} \mathrm{C}$ for $48 \mathrm{~h}$, both in autumn and spring. Prior to analyses, the samples were ground using a pestle and mortar.

Analyses of stable isotopes on these samples were conducted at the Iso-Analytical Ltd. laboratory (Sandbach, U. K.) using an elemental analyser combustion isotope ratio mass spectrometry (precision $\pm 0.1 \%$ ) to obtain values for carbon (C) and nitrogen $(\mathrm{N})$ concentrations, ${ }^{13} \mathrm{C} /{ }^{12} \mathrm{C}$ relative to reference material, and ${ }^{15} \mathrm{~N} /{ }^{14} \mathrm{~N}$ relative to reference material. With this procedure we obtained $\delta$ values for each sample, where $\delta X=\left(\left[R_{\text {sample }} / R_{\text {reference }}\right]-1\right) \times 1000$, where $X$ is the heavier isotope, and $\mathrm{R}$ the ratio of heavy to light isotope.

The reference material used during analysis was IsoAnalytical Working Standard IA-R001, Wheat Flour, with a $\delta^{13} \mathrm{C}$ value of $-26.43 \%$ vs. V-PDB, and a $\delta^{15} \mathrm{~N}$ with a value of $2.55 \%$ vs. air.

We obtained the aquatic food plants for our experiments from different sites (see above). In wetlands, the major sources of available $\mathrm{C}$ and $\mathrm{N}$ for submerged macrophytes are found in the water column and the sediments, although these plants take most of their nutrients from the latter (Thursby and Harlin, 1984; Barko et al., 1991). This means than an aquatic plant species may show differences in $\mathrm{C}$ and $\mathrm{N}$ content due to local variations in availability, and in our case this limited the analysis of potential seasonal differences of isotope values in faeces of coots.

\subsection{Statistical analyses}

We analyzed the effects of coot species, diet type and season on IPS, as well as variations in isotope values in faeces according to food type with analyses of variance (ANOVA) or Student's 
Table 1

Fibre (lignin + cellulose) and protein composition (in \% relative to dry mass) of foods given to red-knobbed and common coots in experiments during autumn and spring

\begin{tabular}{llrccc}
\hline Diet & Season & Fibre & Lignin & Cellulose & Protein \\
\hline Commercial & Autumn & 6.64 & 0.92 & 5.72 & 20.19 \\
& Spring & 7.60 & 1.17 & 6.43 & 19.27 \\
\multirow{2}{*}{ Potamogeton } & Autumn & 43.17 & 19.95 & 23.22 & 13.57 \\
& Spring & 28.40 & 13.22 & 15.18 & 19.78 \\
\hline
\end{tabular}

t-tests. Because the food plants were collected in different sites in spring and autumn, we performed separated analyses for each season when considering isotope values. The data were arc-sin transformed to meet criteria for parametric statistical analyses, which were conducted using STATISTICA (StatSoft, 2001). Mean values are presented with \pm 1 SD unless otherwise stated.

\section{Results}

\subsection{Nutritional quality of foods}

Fibre content was greater in the submerged macrophyte than in commercial food (Table 1). Fibre content in the submerged macrophyte was greater in autumn than in spring (Table 1).
Protein content in commercial food was similar in spring and autumn, and was similar to that recorded in the submerged macrophyte in spring. In autumn, the protein content of P. pectinatus was lower than that in commercial food (Table 1).

\subsection{Faecal particle size}

We present in Fig. 1 the frequency distributions of particle sizes in the red-knobbed and common coots faecal droppings during the experiments according to diet type. There was a statistically significant interaction coot-species $\times$ diet on IPS in the faeces of autumn (two-way ANOVA, $\mathrm{F}_{2,89}=9.5, \mathrm{P}=0.003$, Fig. 2). The IPS for both species was affected by diet type (common coot: $\mathrm{F}_{1,89}=525.1$, P b 0.001; red-knobbed coot: $\mathrm{F}_{1,89}=$ 807.8, P b 0.001). The IPS in faeces of both species was similar when they were fed commercial food $\left(\mathrm{F}_{1,89}=0.34, \mathrm{P}=0.552\right)$, but not when fed P. pectinatus $\left(\mathrm{F}_{1,89}=22.1, \mathrm{P}\right.$ b 0.001). In this last case, the IPS was greater in faeces of red-knobbed coots than in faeces of common coots.

In spring there was also a statistically significant interaction coot-species $\times$ diet on IPS in the faeces (Two-way ANOVA, $\mathrm{F}_{1,87}=6.5, \mathrm{P}=0.01$, Fig. 2). Diet type affected the IPS in faeces (common coot: $\mathrm{F}_{1,87}=208.9$, $\mathrm{P}$ b 0.001 ; red-knobbed coot: $\mathrm{F}_{1,87}=343.4$, P b 0.001). Both species had similar IPS when they fed commercial food $\left(\mathrm{F}_{1,87}=0.004, \mathrm{P}=0.952\right)$, but not when they fed $\mathrm{P}$. pectinatus $\left(\mathrm{F}_{1,87}=10.6, \mathrm{P}=0.002\right)$. In this last
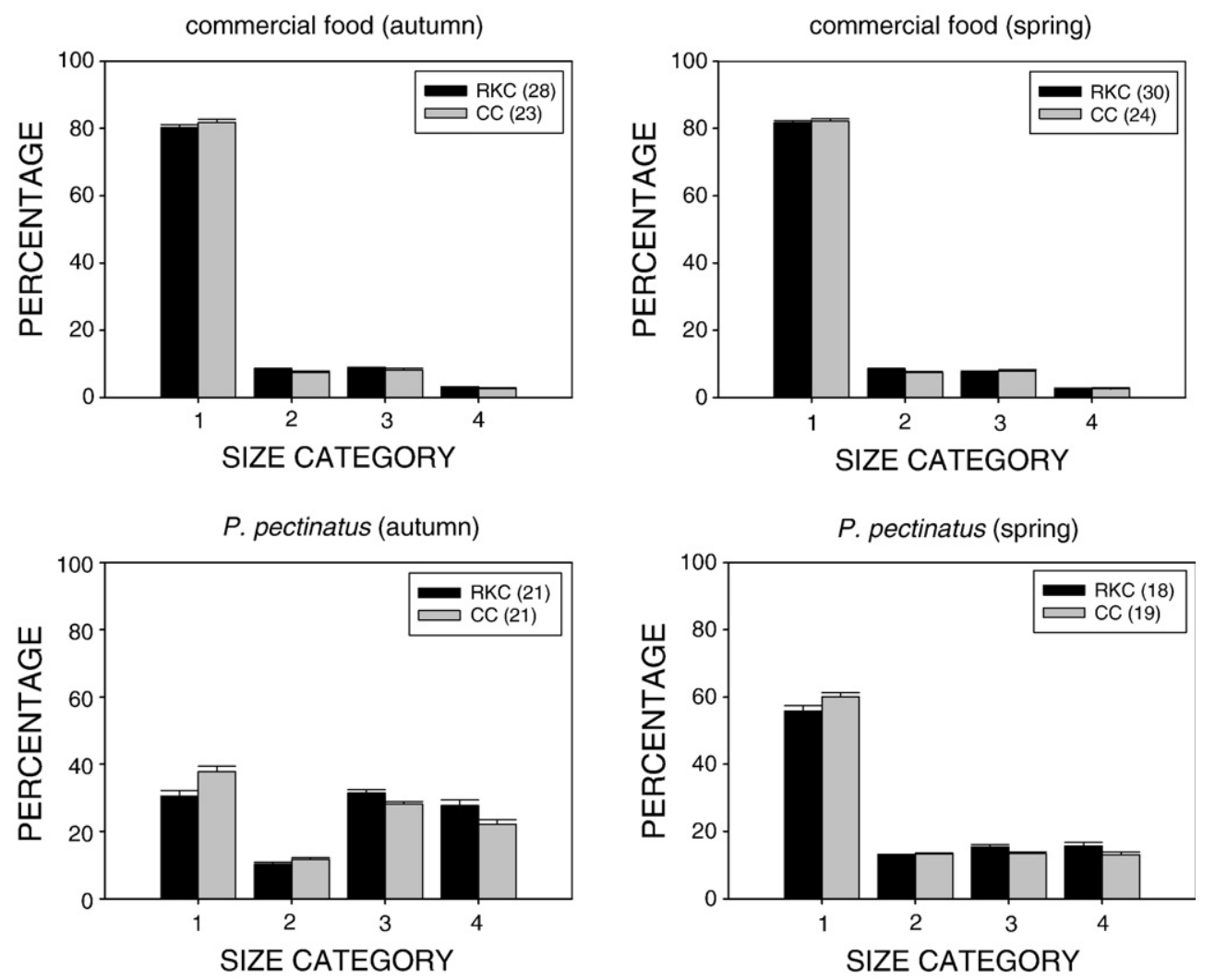

Fig. 1. Mean frequency distributions (\% $\pm 1 \mathrm{SE}$ ) of particle sizes in red-knobbed (RKC) and common coots (CC) faecal droppings in spring and autumn according to food type. The number of faecal droppings examined is in parentheses. The categories of particle size (mm) were: b 0.125 (1), $0.125-0.249$ (2), $0.250-0.499$ (3), and $\geq 500$ (4). 


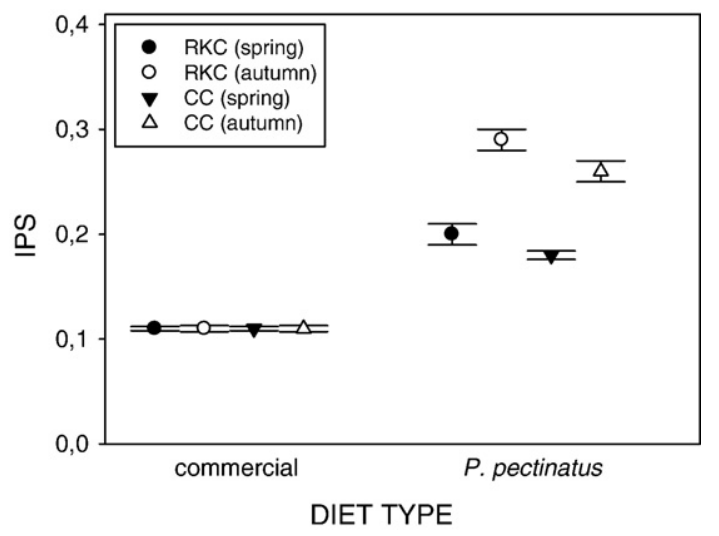

Fig. 2. Mean values ( $\pm 1 \mathrm{SE}$ ) of the Index of Particle Size (IPS) in faeces of redknobbed and common coots fed different diets in spring and autumn. For sample sizes see Fig. 1.

case, IPS of red-knobbed coots was greater than that of common coots (Fig. 2).

Comparisons between seasons indicated that faecal particle sizes of coots fed P. pectinatus were smaller in spring than in autumn (Student's t-tests, $\mathrm{t}_{37}=11.4$ and $\mathrm{t}_{38}=10.5$ for redknobbed coot and common coot, respectively, P b 0.001 in both cases). No seasonal differences in faecal particle size were found neither for red-knobbed $\left(\mathrm{t}_{56}=1.6, \mathrm{P}=0.123\right)$ nor for common coot $\left(\mathrm{t}_{45}=0.4, \mathrm{P}=0.730\right)$ fed commercial food.

\subsection{Stable isotopes in faeces}

We present in Table 2 the isotope values of foods given to both coot species in autumn and spring.

\subsubsection{Excreted $\delta^{13} \mathrm{C}$}

We found no differences between coot species in the isotope values of $C$ in the faeces examined in autumn for neither of the food types (commercial: $\mathrm{F}_{1,8}=0.2, \mathrm{P}=0.634$; Potamogeton: $\mathrm{F}_{1,8}=1.5, \mathrm{P}=0.253$ ) (Table 3).

Similarly, there were no differences between the two coot species in $\delta^{13} \mathrm{C}$ in the faeces of spring according to diet type (commercial: $\mathrm{F}_{1,8}=0.01, \mathrm{P}=0.935$; Potamogeton: $\mathrm{F}_{1,8}=0.003$, $\mathrm{P}=0.987$ ) (Table 3).

\subsubsection{Excreted $\delta^{15} \mathrm{~N}$}

There were no differences between red-knobbed and common coots in $\delta^{15} \mathrm{~N}$ content in faeces of autumn for the commercial food $\left(\mathrm{F}_{1,8}=0.6, \mathrm{P}=0.477\right)$. However, when both coot species were fed $\mathrm{P}$. pectinatus, there were significant differ-

Table 2

$\delta^{15} \mathrm{~N}$ and $\delta^{13} \mathrm{C}$ values (means $\pm \mathrm{SD}$, in all cases $\mathrm{n}=5$ ) in foods given to red$\mathrm{k}$ nobbed and common coots in autumn and spring

\begin{tabular}{llcc}
$\overline{\text { Diet }}$ & Season & $\delta^{15} \mathrm{~N}(\%)$ & $\delta^{13} \mathrm{C}(\%)$ \\
\hline Commercial & Autumn & $1.67 \pm 0.15$ & $-22.18 \pm 0.33$ \\
& Spring & $1.84 \pm 0.15$ & $-21,85 \pm 0.22$ \\
\multirow{2}{*}{ Potamogeton } & Autumn & $8.08 \pm 0.23$ & $-16.27 \pm 0.39$ \\
& Spring & $11.32 \pm 0.28$ & $-22.15 \pm 0.08$
\end{tabular}

Table 3

$\delta^{15} \mathrm{~N}$ and $\delta^{13} \mathrm{C}$ values (means $\pm \mathrm{SD}$, in all cases $\mathrm{n}=5$ ) in faeces of red-knobbed (RKC) and common coots (CC) in spring and autumn according to diet type

\begin{tabular}{lllrl}
\hline Diet & Species & Season & \multicolumn{1}{c}{$\delta^{15} \mathrm{~N}(\%)$} & \multicolumn{1}{l}{$\delta^{13} \mathrm{C}(\%)$} \\
\hline Commercial & RKC & Autumn & $4.97 \pm 1.32$ & $-22.61 \pm 0.73$ \\
& & Spring & $5.28 \pm 1.04$ & $-22.92 \pm 0.90$ \\
& CC & Autumn & $4.30 \pm 1.73$ & $-22.85 \pm 0.82$ \\
& & Spring & $4.24 \pm 0.86$ & $-22.87 \pm 0.86$ \\
Potamogeton & \multirow{2}{*}{ RKC } & Autumn & $9.23 \pm 0.36$ & $-16.44 \pm 0.25$ \\
& & Spring & $15.78 \pm 4.18$ & $-22.18 \pm 0.18$ \\
& CC & Autumn & $8.51 \pm 0.19$ & $-17.00 \pm 0.98$ \\
& & Spring & $11.33 \pm 0.99$ & $-22.18 \pm 0.24$ \\
\hline
\end{tabular}

ences in the $\delta^{15} \mathrm{~N}$ content of their faeces in autumn $\left(\mathrm{F}_{1,8}=15.9\right.$, $\mathrm{P}=0.004$ ) (Table 3). In comparison to the faeces of red-knobbed coots fed P. pectinatus, those of common coots were depleted $0.72 \%$ in $\delta^{15} \mathrm{~N}$.

There were significant differences between red-knobbed and common coots in $\delta^{15} \mathrm{~N}$ content in faeces of spring when fed P. pectinatus $\left(\mathrm{F}_{1,8}=6.2, \mathrm{P}=0.037\right)$, but not when fed commercial food $\left(\mathrm{F}_{1,8}=3.1, \mathrm{P}=0.118\right)$ (Table 3$)$. The faeces of redknobbed coots fed P. pectinatus were enriched $4.45 \%$ in $\delta^{15} \mathrm{~N}$ in comparison to those of common coots.

\section{Discussion}

Common and red-knobbed coots mainly forage on aquatic submerged macrophytes (Cramp and Simmons, 1980; Fairall, 1981; Fernández-Palacios and Raya, 1991; Taylor and Van Perlo, 1998). Although in southwestern Spain both species are sympatric and feed on the same plant species (FernándezPalacios and Raya, 1991) our results suggest that there are differences in their efficiencies of food assimilation.

The size of particles was greater in the faeces of red-knobbed coots than in those of common coots fed natural foods. For both species faecal particles were larger in autumn than in spring. Some herbivorous waterbirds show size-related selective retention of particles in the digestive tract, so that small particles are retained in the ceca, whereas large particle pass more quickly through the large intestine (see review in Durant, 2003). A longer retention of particles facilitates digestion (Bjorndal et al., 1990; Clauss et al., 2004). Consequently, seasonal differences in faecal particle size suggest that feeding assimilation for the two species would be higher in spring, when the fibre content in natural foods was lower, than in autumn. Moreover, the larger size of particles in the faeces of the red-knobbed coots in comparison to the common coots implies that the former species would be a less efficient digester of food than the latter. Fairall's (1981) results also suggest that red-knobbed coots may not be very efficient digesters of some types of food.

Differences among $\delta^{13} \mathrm{C}$ values are useful to detect different sources of C in the diet of consumers (Fry and Sherr, 1984; Haramis et al., 2001; Hobson et al., 2003; Sponheimer et al., 2003a). In accordance with this, we found no significant between-coot species differences in $\delta^{13} \mathrm{C}$ values in the faeces for neither of the diets.

The faeces of the two coot species were more enriched in ${ }^{15} \mathrm{~N}$ than the diet. Similar results have been reported for other 
herbivores (see review in Hwang et al., 2007). The physiological mechanism causing this enrichment of ${ }^{15} \mathrm{~N}$ in faeces is not known (Hwang et al., 2007). We found no differences in $\delta^{15} \mathrm{~N}$ values in faeces when coots were fed commercial food, neither in autumn nor in spring. However, $\delta^{15} \mathrm{~N}$ values were higher in faeces of red-knobbed coots than in faeces of common coots when the birds were fed the aquatic macrophyte. We assume that the nutrient contents of the food plants were the same for both coot species, so that between-coots differences in $\delta^{15} \mathrm{~N}$ values in faeces could be explained by differences in isotope fractionation during digestive processes (Hobson and Clark, 1992; Webb et al., 1998; Oelbermann and Scheu, 2002; Sponheimer et al., 2003a; Podlesak et al., 2005). Therefore, although both coot species were fed the same food plants collected in the same sites, between-coot species differences in $\delta^{15} \mathrm{~N}$ values in faeces would indicate that the food plants would not be of the same nutritional quality for each species (Hobson and Clark, 1992).

Uric acid is the major nitrogen excretion product in birds, and is depleted in ${ }^{15} \mathrm{~N}$ relative to diet (Hobson et al., 1993; Vanderklift and Ponsard, 2003). In addition, faecal ${ }^{15} \mathrm{~N}$ losses also include undigested nitrogen from food (Sponheimer et al., 2003a,b; Codron et al., 2005). This indicates that differences in $\delta^{15} \mathrm{~N}$ in the excreta of animals that had been fed the same diet may due to differences in nitrogen use efficiency. Thus, the higher $\delta^{15} \mathrm{~N}$ values in faeces of red-knobbed coots than in faeces of common coots would indicate a lower enrichment of ${ }^{15} \mathrm{~N}$ in body tissues of the former species, suggesting that the digestive efficiency of the former species was lower than that of the latter. The mechanism causing this pattern would lie in the apparently lower ability of red-knobbed coots to break down their food, as suggested by larger particle size in faeces when the fibre content in food plants increased. The fact that birds maintained body mass could have resulted, therefore, from differences in food intake between the two coot species, indeed under field conditions the red-knobbed coots always spend more time foraging than the sympatric common coots (Varo, 2007).

Although in this study we employed two novel techniques have not been validated, our results are consistent with the predictions in that (1) when fibre content is low there are no differences between species, and (2) differences are apparent when fibre content increases. These results may have implications to explain differences in the ecological performance of both species, which in southern Spain have similar clutch sizes and hatch a similar number of chicks. Nevertheless, fledging success is much lower for red-knobbed than for common coots and these differences are exacerbated when water levels in wetlands are lower (Varo, 2007). It has been suggested that the hydroperiod in southern Spanish wetlands have shortened during the last decades as a result of accelerated rates of siltation processes derived from changes in agricultural practices in the basins of wetlands, and this may have had an effect on the length of periods during which submerged macrophytes of high nutritive quality are available to waterbirds (Amat and Raya, 2004). As the results of our study suggest, the red-knobbed coot would be more adversely affected by these habitat alterations than the common coot. Therefore, differences in food assimila- tion between both coot species with increasing fibre content suggest that physiology may play a role in explaining the conservation problems of the red-knobbed coot in Spain.

The management of water depth in wetlands may be an important tool to conserve the red-knobbed coot in Spain, given the likely effect that a longer hydroperiod may have on submerged macrophyte production. Because wetland productivity is greater following reflooding after a period of drought (Briggs and Maher, 1985; Crome, 1986), management actions should allow for periodic drying and reflooding. Given that the habitat of the red-knobbed coot is very dynamic, and the coots respond to changing water conditions by shifts in spatial distribution (Douthwaite, 1978; Varo, 2007) management actions should be accomplished over large areas rather than on specific sites, ensuring that high quality habitat is available during drought periods (see Bennetts and Kitchens, 1997; Brock et al., 2003). This type of management should be carefully planned to ensure that other species are not negatively impacted.

To sum up, our results highlight the importance of physiological restrictions to understand individual responses to changes in the quality of feeding resources, and acknowledging this may be crucial to the successful implementation of conservation plans. We concur with Carey (2005) and Wikelski and Cooke (2006) in that the consideration of physiological principles may be very important in understanding the causes of population declines, and in that the precise determination of such causes may be essential to provide recommendations to wildlife managers.

\section{Acknowledgements}

We thank Maribel Adrián and Plácido Rodríguez for allowing us to conduct the experiments at "Cañada de los Pájaros," as well as for their help in capturing coots. Our thanks also to Manuel and Serafín Vázquez for their technical assistance. Consejería de Medio Ambiente (Junta de Andalucía) authorized the experiments. The study was funded by an agreement between Consejería de Medio Ambiente (Junta de Andalucía) and Consejo Superior de Investigaciones Científicas with EU-ERDF support. Manuela G. Forero, Andy J. Green and José A. Masero commented on an earlier version of this paper.

\section{References}

Amat, J.A., 1984. Las poblaciones de aves acuáticas en las lagunas andaluzas: composición y diversidad durante un ciclo anual. Ardeola 31, 61-79. Amat,

J.A., Raya, C., 2004. Focha moruna Fulica cristata. In: Madroño, A., González, C., Atienza, J.C. (Eds.), Libro Rojo de las Aves de España. Dirección General para la Biodiversidad-SEO/Birdlife, Madrid, pp. 199-202.

Barko, J.W., Gunnison, D., Carpenter, S.R., 1991. Sediment interactions with submersed macrophyte growth and community dynamics. Aquat. Bot. 41, 41-65.

Bennetts, R.E., Kitchens, W.M., 1997. Population dynamics and conservation of snail kites in Florida: the importance of spatial and temporal scale. Colon. Waterbirds 20, 324-329.

Bernis, F., 1964. Información Española sobre Anátidas y Fochas. Época Invernal. Sociedad Española de Ornitología, Madrid.

Bjorndal, K.A., Bolten, A.B., Moore, J.E., 1990. Digestive fermentation in herbivores: effect of food particle size. Physiol. Zool. 63, 710-721. 
Briggs, S.V., Maher, M.T., 1985. Limnological studies of waterfowl habitat in south-western New South Wales. II. Aquatic macrophyte productivity. Aust. J. Mar. Freshw. Res. 36, 707-715.

Brock, M.A., Nielsen, D.L., Shiel, R.J., Green, J.D., Langley, J.D., 2003. Drought and aquatic community resilience: the role of eggs and seeds in sediments of temporary wetlands. Freshw. Biol. 48, 1207-1218.

Buchsbaum, R., Wilson, J., Valiela, I., 1986. Digestibility of plant constituents by Canada geese and Atlantic brant. Ecology 67, 386-393.

Carey, C., 2005. How physiological methods and concepts can be useful in conservation biology. Integr. Comp. Biol. 45, 4-11.

Carmichael, R.H., Rutecki, D., Annett, B., Gaines, E., Valiela, I., 2004. Position of horseshoe crabs in estuarine food webs: $\mathrm{N}$ and $\mathrm{C}$ stable isotopic study of foraging ranges and diet composition. J. Exp. Mar. Biol. Ecol. 299, 231-253.

Caviedes-Vidal, E., Afik, D., Martínez del Río, C., Karasov, W.H., 2000. Dietary modulation of enzymes of the house sparrow (Passer domesticus): testing an adaptive hypothesis. Comp. Biochem. Physiol. 125A, 11-24.

Clauss, M., Schwarm, A., Ortmann, S., Alber, D., Flasch, E.J., Kuehne, R., Hummel, J., Streich, W.J., Hofer, H., 2004. Intake, ingest retention, particle size distribution and digestibility in the Hippopotamidae. Comp. Biochem. Physiol. 139A, 449-459.

Codron, D., Codron, J., Lee-Thorp, J.A., Sponheimer, M., de Ruiter, D., 2005. Animal diets in the Waterberg based on stable isotope composition of faeces. S. Afr. J. Wildl. Res. 35, 43-52.

Codron, D., Codron, J., Lee-Thorp, J.A., Sponheimer, M., de Ruiter, D., Sealy, J., Grant, R., Fourie, N., 2007. Diets of savanna ungulates from stable carbon isotope composition of faeces. J. Zool. 273, 21-29.

Cornelissen, J.H.C., Quested, H.M., Gwynn-Jones, D., Van Logtestijn, R.S.P., De Beus, M.A.H., Kondratchuk, A., Callaghan, T.V., Aerts, R., 2004. Leaf digestibility and litter descomposability are related in a wide range of subarctic plant species and types. Funct. Ecol. 18, 779-786.

Cramp, S., Simmons, K.E.L. (Eds.), 1980. The Birds of the Western Palearctic, vol. 2. Oxford Univ. Press, Oxford.

Crome, F.H.J., 1986. Australian waterfowl do not necessarily breed on a rising water level. Aust. Wildl. Res. 13, 461-480.

Douthwaite, R.J., 1978. Geese and red-knobbed coot on the Kafue Flats in Zambia, 1970-1974. East Afr. Wildl. J. 16, 29-47.

Drobney, R.D., 1984. Effect of diet on visceral morphology of breeding wood ducks. Auk 101, 93-98.

Durant, D., 2003. The digestion of fibre in herbivorous Anatidae - a rewiew. Wildfowl 54, 7-24.

Fairall, N., 1981. A study of the bioenergetics of the redknobbed coot Fulica cristata on a South African estuarine lake. S. Afr. J. Wildl. Res. 11, 1-4.

Fernández-Palacios, J., Raya, C., 1991. Biología de la focha cornuda (Fulica cristata) en el Bajo Guadalquivir: situación y biología. Alytes 6, 159-185.

Fry, B., 2006. Stable Isotope Ecology. New York, Springer.

Fry, B., Sherr, E.B., 1984. $\delta 13 \mathrm{C}$ measurements as indicators of carbon flow in marine and freshwater ecosystems. Contrib. Mar. Sci. 27, 13-47.

Ganes, L.Z., Martínez del Río, C., Koch, P., 1998. Natural abundance variations in stable isotopes and their potential use in animal physiological ecology. Comp. Biochem. Physiol., A 119, 725-737.

Haramis, G.M., Jorde, D.G., Macko, S.A., Walker, J.L., 2001. Stable-isotope analysis of canvasback winter diet in upper Chesapeake Bay. Auk 118, 1008-1017.

Hobson, K.A., Clark, R.G., 1992. Assessing avian diets using stable isotopes II: factors affecting diet-tissue fractionation. Condor 94, 189-197.

Hobson, K.A., Alisauskas, R.T., Clark, R.G., 1993. Stable-nitrogen isotope enrichment in avian tissues due to fasting and nutritional stress: implications for isotopic analyses of diet. Condor 95, 388-394.

Hobson, K.A., Wassenaar, L.I., Milá, B., Lovette, I., Dingle, C., Smith, T.B., 2003. Stable isotopes as indicators of altitudinal distributions and movements in an Ecuadorean hummingbird community. Oecologia 136, 302-308.

Hwang, Y.T., Millar, J.S., Longstaffe, F.J., 2007. Do $\delta 15 N$ and $\delta 13 C$ values of feces reflect the isotopic composition of diets in small mammals? Can. J. Zool. 85, 388-396.
Jones, R.I., King, L., Dent, M.M., Maberly, S.C., Gibson, C.E., 2004. Nitrogen stable isotope ratios in surface sediments, epilithon and macrophytes from upland lakes with differing nutrient status. Freshw. Biol. 49, 382-391.

Karasov, W.H., 1986. Energetics, physiology and vertebrate ecology. Trends Ecol. Evol. 1, 101-104.

Karasov, W.H., 1990. Digestion in birds: chemical and physiological determinants and ecological interactions. Stud. Avian Biol. 13, 391-415.

Kehoe, F.P., Ankney, C.D., Alisauskas, R.T., 1988. Effects of dietary fiber and diet diversity on digestive organs of captive mallards (Anas platyrhynchos). Can. J. Zool. 66, 1597-1602.

López-Calleja, M.V., Bozinovic, F., 1999. Feeding behavior and assimilation efficiency of the rufous-tailed plantcutter: a small avian herbivore. Condor 101, 705-710.

Livezey, B.C., 1998. A phylogenetic analysis for the Gruiformes (Aves) based on morphological characters, with an emphasis on the rails (Rallidae). Philos. Trans. R. Soc. Lond., B 353, 2077-2151.

Menéndez, M., 2002. Net production of Ruppia cirrhosa in the Ebro Delta. Aquat. Bot. 73, 107-113.

Oelbermann, K., Scheu, S., 2002. Stable isotope enrichment ( $\delta 15 \mathrm{~N}$ and $\delta 13 \mathrm{C}$ ) in a generalist predator (Pardosa lugubris, Araneae:Lycosidae): effects of prey quality. Oecologia 130, 337-344.

Podlesak, D.W., McWilliams, S.R., Hatch, K.A., 2005. Stable isotopes in breath, blood, feces and feathers can indicate intra-individual changes in the diet of migratory songbirds. Oecologia 142, 501-510.

Santamaría, L., Hootsmans, M.J.M., 1998. The effect of temperature on the photosynthesis, growth and reproduction of a Mediterranean submerged macrophyte, Ruppia drepanensis. Aquat. Bot. 60, 169-188.

Sponheimer, M., Robinson, T., Ayliffe, L., Passey, B., Roeder, B., Shipley, L., Lopez, E., Cerling, T., Dearing, D., Ehleringer, J., 2003a. An experimental study of carbon-isotope fractionation between diet, hair, and feces of mammalian herbivores. Can. J. Zool. 81, 871-876.

Sponheimer, M., Robinson, T., Ayliffe, L., Roeder, B., Hammer, J., Passey, B., West, A., Cerling, T., Dearing, D., Ehleringer, J., 2003b. Nitrogen isotopes in mammalian herbivores: hair $\delta 15 \mathrm{~N}$ values from a controlled feeding study. Int. J. Osteoarchaeol. 13, 80-87.

StatSoft, Inc., 2001. STATISTICA (Data analysis software system), Version 6. StatSoft, Tulsa.

Taylor, B., Van Perlo, B., 1998. Rails: A Guide to the Rails, Crakes, Gallinules and Coots of the World. Pica Press, Sussex.

Thursby, G.B., Harlin, M.M., 1984. Interactions of leaves and roots of Ruppia maritima in the uptake of phosphate, ammonia and nitrate. Mar. Biol. 83, 61-67.

Vanderklift, M.A., Ponsard, S., 2003. Sources of variation in consumer-diet $\delta 15$ N enrichment: a meta-analysis. Oecologia 136, 169-182.

Van Soest, P.J., 1996. Allometry and ecology of feeding behavior and digestive capacity in herbivores: a review. Zoo Biol. 15, 455-479.

Van Wijk, R.J., 1988. Ecological studies on Potamogeton pectinatus L.I. General characteristics, biomass production and life cycles under field conditions. Aquat. Bot. 31, 211-258.

Varo, N., 2007. Ecología de las fochas moruna, Fulica cristata, y común, Fulica atra, en un área de simpatría. Ph. D. Thesis, Univ. Seville.

Veloso, C., Bozinovic, F., 1993. Dietary and digestive constraints on basal energy metabolism in a small herbivorous rodent. Ecology 74, 2003-2010.

Webb, S.C., Hedges, R.E.M., Simpson, S.J., 1998. Diet quality influences the $\delta 13 \mathrm{C}$ and $\delta 15 \mathrm{~N}$ of locusts and their biochemical components. J. Exp. Biol. 201, 2903-2911.

Wikelski, M., Cooke, S.J., 2006. Conservation physiology. Trends Ecol. Evol. 21, 38-46.

Ziswiler, V., Farner, D.S., 1972. In: Farner, D.S., King, J.R. (Eds.), Digestion and the digestive system. Avian Biology, vol. 2. Academic Press, New York, pp. 343-430. 